\title{
Tobacco marketing in California and implications for the future
}

\author{
April Roeseler, ${ }^{1}$ Ellen C Feighery, ${ }^{2}$ Tess Boley Cruz ${ }^{3}$
}

${ }^{1}$ California Department of Public Health, California Tobacco Control Program, Sacramento, California, USA

International Research, Campaign for Tobacco Free Kids, Washington, DC, USA ${ }^{3}$ Preventive Medicine, University of Southern California, Keck School of Medicine, Los Angeles, California, USA

\section{Correspondence to} April Roeseler, Programs and Media Operations Section, California Department of Public Health, CDIC/California Tobacco Control Program, MS 7206, P0 Box 997377, Sacramento, CA 95899-7377, USA; April.Roeseler@cdph.ca.gov

Received 3 June 2009 Accepted 8 January 2010

\section{ABSTRACT}

Background Tobacco marketing influences tobacco use initiation, maintenance of use, and it undermines comprehensive tobacco control programmes. Policies to ban the impact of tobacco marketing are most likely to be more effective if they are comprehensive, as partial bans shift marketing to non-banned forms of media. A comprehensive approach to reducing tobacco marketing includes documentation through monitoring, media and policy interventions and aggressive enforcement of existing laws.

Methods This paper summarises California tobacco industry monitoring of events and retail outlets, and findings about exposure to and beliefs about tobacco industry marketing among youths and adults conducted during the period 2000 through 2008.

Results There was no overall change in the average number of cigarette materials per store, and an increase in the percentage of stores with advertisements promoting price discounts for cigarettes. Stores with cigarette advertisements near candy displays declined from $12.5 \%$ (95\% Cl $9.8 \%$ to $15.2 \%$ ) to $1 \%$ (95\% Cl $0.2 \%$ to $1.9 \%$ ) of stores, and advertisements at or below the eye-level of children declined from $78.6 \%(95 \% \mathrm{Cl} 75.2 \%$ to $82.0 \%$ ) to $31 \%$ (95\% Cl $27.1 \%$ to $34.9 \%$ ) of stores. Overall, the number of public events with tobacco sponsorship declined from $77.3 \%$ to $48.1 \%$. This trend was consistent with a significant decline noted among high school students and adults who reported seeing tobacco advertisements at events or attending a tobacco company-sponsored event.

Conclusions Tobacco industry monitoring, media, policy and enforcement interventions may have contributed to observed changes in tobacco marketing and to declines in reported exposure to tobacco marketing.

\section{BACKGROUND}

Tobacco industry marketing encompasses planned efforts to convince people to desire, buy or support tobacco company interests using methods that include paid advertising, price promotions, public relations and distribution of tobacco products and promotional items. ${ }^{1}$ These marketing strategies are an important factor affecting individual uptake, ${ }^{2}$ maintenance of tobacco use, and they impact the success of comprehensive tobacco control programmes in ways that extend beyond its effect on individual tobacco users. ${ }^{3}$ Exposure to point-ofsale tobacco promotions influences susceptibility to smoking, smoking initiation, impulse tobacco purchases and undermines quitting. ${ }^{4} 5$ Price promotions undermine the effect of tobacco taxes to reduce tobacco consumption and smoking prevalence by increasing the affordability of tobacco products, ${ }^{6-9}$ while political campaign contributions, sponsorship, philanthropy and corporate responsibility efforts subtly influence tobacco-related policy decisions made by elected officials, community leaders, constituency groups and even juries. ${ }^{10-16}$

The California Department of Public Health (CDPH), California Tobacco Control Program (CTCP) has continuously monitored exposure to and beliefs about tobacco industry marketing among adults and youths through telephone and in-school surveys. These population-based surveys are supplemented with observational surveys of tobacco marketing focused on sponsored events and the retail environment. This paper describes California's media and programme interventions to stimulate tobacco marketing restrictions; enforcement of the Master Settlement Agreement ${ }^{i}$ (MSA), Smokeless Tobacco Settlement Agreement and existing laws; and reports on changes in marketing, and adult and youth attitudes about and exposure to tobacco industry marketing in California.

\section{Sponsorship}

Sponsorship occurs when a company pays money to an event organiser, site owner or competitor in exchange for access to the audience, promotional rights and use of the event or property trademarks. ${ }^{11}$ It is an important form of marketing because it allows tobacco companies to associate their name and brands with a desirable lifestyle image, people's pastimes and passions, ${ }^{17-19}$ and provides tobacco companies the ability to circumvent the 1971 ban on marketing cigarettes in the broadcast media. ${ }^{20}$ Viewers of tobacco-sponsored sporting events have more brand awareness, more favourable attitudes towards tobacco use and preferences for specific tobacco brands. ${ }^{21} 22$ Sponsorship also occurs at adult-only facilities such as bars, clubs and fraternities. These staged marketing opportunities usually involve distributing free product samples, coupons and promotional items to build brand awareness, introduce a new product, encourage experimentation, retain and build customer loyalty, and generate names for direct mail. ${ }^{23-25}$ Attendance at these events has been associated with higher smoking prevalence among college students. ${ }^{26}$

'The 1998 Master Settlement Agreement (MSA) and the Smokeless Tobacco Master Settlement Agreement (STMSA) are legal contracts established between 46 states, including California, and five US territories, with participating tobacco manufacturers. The MSA and STMSA provide numerous restrictions and prohibitions, including bans on the use of cartoons in tobacco advertisements, youth exposure to sampling, certain sponsorships, and the use of most outdoor advertisements. Tobacco Litigation and Enforcement. California Office of the Attorney General. Available from: http://ag. ca.gov/tobacco/index.php (accessed 29 September 2008). 
In 2006, US cigarette companies spent $\$ 168$ million on sponsoring public entertainment, and smokeless tobacco companies spent $\$ 144000$ on this marketing category. Cigarette companies reported spending $\$ 29$ million on free sample distribution in 2006 while smokeless tobacco companies spent $\$ 42$ million on free samples. ${ }^{27} 28$

\section{Retail environment}

Retail outlets are an important environment for tobacco companies to promote their products, segment the market and target groups they might lose such as those thinking about quitting or who have recently quit. In-store marketing strategies to achieve these goals include point-of-sale advertising, payments for prime product placement and a variety of price discounting tools. ${ }^{4}$ Numerous studies document the influence of point-of-purchase tobacco marketing and price promotions on smoking initiation, movement along the smoking continuum to a regular smoker and undermining of quit efforts. ${ }^{3} 4$

In 2006, point-of-sale advertising led traditional tobacco advertising expenditures among cigarette and smokeless tobacco companies at approximately $\$ 243$ million for cigarette companies and \$21 million for smokeless tobacco companies. ${ }^{27} 28$ However, price-related marketing strategies dominated marketing expenditures of both cigarette and tobacco companies in $2006{ }^{27} 28$ Price promotions are frequently linked to contractual agreements between the tobacco companies and retailers to offer volume discounts and financial incentives to secure product placement and marketing materials where they will be noticed by consumers. ${ }^{29}$

The trend towards price-related marketing relative to expenditures for image-oriented cigarette advertising began in the late 1980s. ${ }^{25}$ Following the 1998 MSA which banned tobacco billboard advertising and placed restrictions on other forms of traditional advertising and promotions, this trend was accelerated. $^{4253031}$ In 2006, cigarette companies allocated 93\% (\$11.5 billion) of all their advertising and promotions expenditures toward price-related strategies (promotional allowances, coupons, retail value added and price discounts) and smokeless tobacco companies spent 69\% (\$246 million) of all their advertising and promotion expenditures on these categories. ${ }^{27} 28$

\section{Media and programme interventions to address tobacco marketing}

Since 1990, California's media campaign has raised awareness about the tobacco industry's marketing practices and sought to shape attitudes that support placing restrictions on tobacco marketing. As illustrated in figure 1, a 1994 outdoor advertisement called attention to tobacco company sponsorship of motorsport events and their appeal to youth. Between 2001 and 2004 a television advertising campaign featuring Ken Lane, a fictional tobacco industry marketing executive, was aired. These advertisements, which are available from the Centers for Disease Control Media Resource Center, discussed tobacco industry marketing, (eg, sponsorship of motorsports, in-store advertising and target marketing). ${ }^{32}$ Figure 2 displays a print advertisement from the Ken Lane campaign, which raised awareness about the strategic placement of tobacco advertisements in stores. More recently, the 2009 Grim Reapers television advertisement called attention to the deadly nature of distributing free tobacco products. ${ }^{33}$ See figure 3.

In addition to the media campaign, three statewide advocacy campaigns mobilised community efforts to address tobacco marketing. Each campaign provided training and electronic or print toolkits for tobacco control projects, including instruments to monitor tobacco marketing, sample policies, talking points and educational and public relations materials. ${ }^{34-43}$

The first campaign, Operation Storefront: Youth Against Tobacco Advertising and Promotions began in 1994 (A Roeseler, C Russell, E Feighery, et al, unpublished report, 1995). This campaign sought to restrict the placement of in-store tobacco advertising in locations where it was likely to be seen by youths and to stimulate enforcement of existing laws that restrict placement of exterior retail advertising. Compliance with these exterior signage laws, which were originally enacted for beautification (eg, prohibit outdoor sandwich board signs) or public safety purposes (eg, limits on the percentage of a store window that may be covered by advertising to ensure the store interior is visible to police from the outside), reduces tobacco advertising. ${ }^{44}$ By 2001, approximately 40 California cities and counties had enacted ordinances restricting in-store tobacco advertising or outdoors in locations frequented by minors. ${ }^{45}$ These ordinances were nullified as the result of the US Supreme Court Lorillard Tobacco Co v Reilly (533 US 525 (2001) decision which struck down a Massachusetts regulation prohibiting tobacco product advertising within 1000 feet of any school or playground. ${ }^{4}$

A second CTCP campaign, initiated in 1997 was Project SMART (Sponsorship Mission: Avoid Reliance on Tobacco) Money. It focused on reducing tobacco industry event sponsorship and free tobacco product sampling through policy adoption and enforcement of existing sampling laws (TB Cruz, N Preacely, unpublished report, 2005). California policies to eliminate tobacco-related event sponsorship include 22 state, county and local fair board policies, seven rodeo-level policies and 20 university, college and community level policies prohibiting tobacco sponsorship or advertising. ${ }^{46-48}$

California state law prohibits tobacco sampling in many locales, but permits it in adult-only facilities. ${ }^{49}$ As of 2009 , there were 47 ordinances restricting the free distribution of tobacco products in California. ${ }^{50}$ One of the strongest of these is the city of Chico's 2007 ban on the non-sale distribution of smokeless tobacco and cigarettes, coupons and rebates in locations including bars, fraternities, sororities, convenience stores and gas stations. ${ }^{51}$ This college community has a population of 69000 and a student population of 17000 at California State University Chico. Before its ordinance, the US Smokeless Tobacco Company (USST) sponsored bar nights in the city, and parties at the university's fraternities and sororities. Students were often hired to give away free samples of tobacco products along with promotional items, including T-shirts, shot glasses and lighted necklaces in exchange for personal information. ${ }^{52} 53$

The third statewide advocacy effort launched was the STORE (Strategic Tobacco Retail Effort) Campaign in 2002. It took a comprehensive approach to the retail environment in terms of tobacco marketing and sales. ${ }^{43}$ This campaign helped build momentum for local tobacco retail licensing and self-service display bans. From 1998 to September 2009, 102 tobacco retail licensing ordinances were enacted which cover about $57 \%$ of the state's population. ${ }^{54}$ The number of self-service tobacco sales bans enacted increased from 27 in 1994 to 157 in July 2009. ${ }^{54} 55$ The large number of local self-service display ordinances facilitated passage of a statewide self-service display ban on cigarettes in 2002, which was expanded to include other tobacco products in $2004 .^{5657}$

\section{California Attorney General Office collaboration}

The campaigns described above were complemented by aggressive enforcement activity by the California Attorney General's Office. The California Attorney General's Office used documentation 
Figure 1 California Tobacco Control Program outdoor advertisement to raise awareness about tobacco company sponsorship of car racing events and their appeal to youth.

\section{KIDS LOVE RAGE CARS. UNFORTUNATELY, SO DOES THE TOBACCO INDUSTRY.}

provided by state and local tobacco control programmes to pursue enforcement and lawsuits against tobacco companies and to compel large corporate retailers to enter into voluntary agreements to abide by business practices aimed at reducing illegal tobacco sales to minors. Since 2000, the California Attorney General's Office efforts resulted in 14 successful enforcement actions against tobacco companies totalling more than \$24 million in payments, penalties and fees. Of these payments, nearly $\$ 1.9$ million was earmarked for tobacco control. Eight $(57 \%)$ of the enforcement actions involved violations of the MSA and six (43\%) were for violations of California state law regulating the non-sale distribution of tobacco products. RJ Reynolds and USST were responsible for 13 (93\%) of these enforcement actions. Appendix 1 provides additional details. ${ }^{58-72}$

In 2002 the California Attorney General's Office negotiated with the Coalition for Responsible Tobacco Retailing and Philip Morris to revise information and materials they distributed to

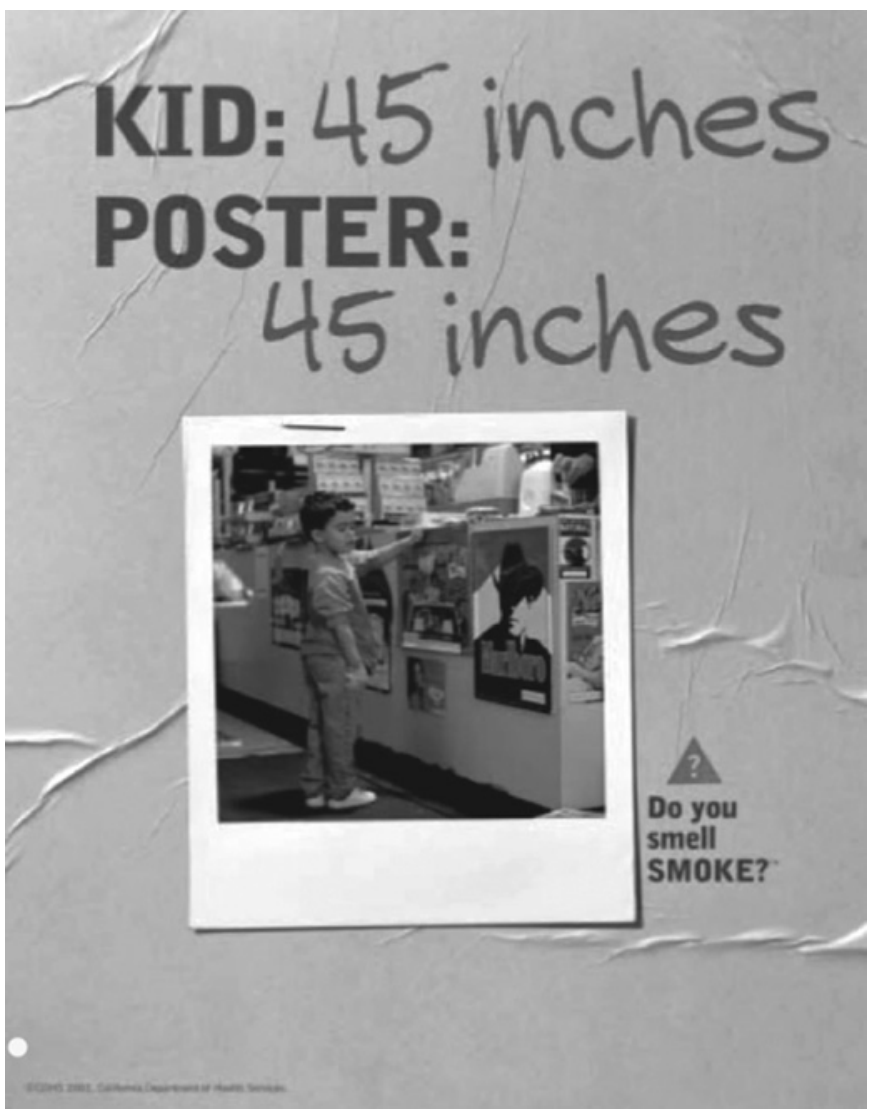

Figure 2 California Tobacco Control Program print advertisement to raise awareness about retail tobacco advertising placed at the eye-level of children. retailers to educate them about mandated age-of-sale warning sign requirements and to communicate that the use of the We Card sign did not comply with State law. ${ }^{73}$ In partnership with other state attorneys general, it also negotiated voluntary agreements with 12 major chain retail convenience, drug store, gas station and grocery stores to implement meaningful business practices to reduce tobacco sales to minors. An additional agreement with a California grocery store chain resulted from litigation. $^{74}$

\section{METHODS}

California's tobacco industry monitoring system collects data on tobacco marketing at public events, in the retail environment and from adults and youths through telephone and in-school surveys. An abbreviated description of each survey's methodology is described here with references given to obtain a full description.

\section{Event sponsorship monitoring methods}

From 2001 to 2003, tobacco industry event sponsorship monitoring and analyses were conducted by the University of Southern California (USC). Beginning in 2006, Population Research System (PRS) took over the data collection with CTCP conducting the analyses. No statewide tobacco industry event sponsorship data were collected during 2004 and 2005.

During the 2004 to 2005 transition, the USC data collection instrument was revised. Open-ended questions were converted to close-ended multiple choice questions to standardise data

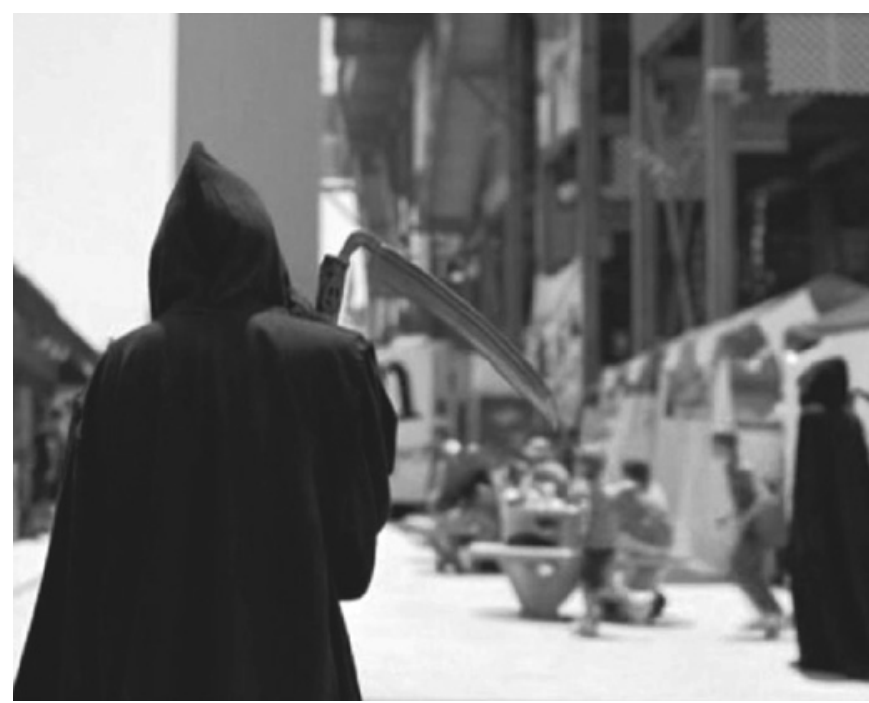

Figure 3 Scene from California Tobacco Control Program television advertisement to raise awareness about the deadly nature of free tobacco product distribution. 
collection and analysis. Survey instruments from both USC and PRS collected data on event information, tobacco industry sponsorship, youth activities at the event, the presence of adult-only areas and event attendance. The methodology to estimate audience size varied slightly between the two surveys.

Owing to funding limitations, a purposive sampling plan was used to select events for observation. Selection criteria were based on past history of the event including having a large audience, a tobacco-sponsored adult-only area, the free distribution of tobacco products, presence of a mobile electronic scoreboard or previous history of tobacco marketing violations at similar event types. Both USC and PRS placed a pre-event telephone call to confirm the date, location, ticket information and information about tobacco industry sponsorship.

USC staff and volunteers from CTCP-funded projects conducted observations from 2001 to 2003. Beginning in 2006, only paid observers were used. For the period 2001-2003, observers were provided with written instructions and a video training programme on how to complete the forms. Completed observation forms, tobacco promotional materials and photographs from the event were mailed to USC where the data were entered into a database.

Beginning in 2006, observers were trained by CTCP staff. Completed observation forms were scanned and emailed to PRS following the event observation. Observations forms, the event programme, promotional materials and photographs were also electronically scanned and uploaded to a file transfer protocol (ftp) site by the data collectors. The California Attorney General's Office was provided access to the ftp site to monitor the data for potential MSA violations.

\section{Retail environment monitoring methods}

The California Tobacco Assessment Study is a longitudinal prospective cohort study of California stores that sell tobacco. Since 2000, six survey waves were conducted to assess tobacco marketing materials in the retail environment. The survey was conducted in 2000, annually from 2002 to 2005 and in 2008. The baseline study sample was based on a 1997 randomly selected sample of California stores that sold cigarettes. Each year, stores that were found to be 'no longer in business' were replaced with new randomly selected stores from the original sampling frame. Trained paid observers collected data on the amount, placement and type of branded cigarette marketing materials, and functional items (eg, trash cans and coin trays); placement of advertisements; posting of tobacco age-of-sale warning signs and the required tobacco retail licence; and compliance with the ban on self-service displays of tobacco. Further information on the methods and analyses can be found in a paper by Feighery et al. ${ }^{75}$

\section{Telephone surveys and in-school survey methods}

Perceptions of and exposure to tobacco marketing are collected through telephone and in-school surveys. The California Adult Tobacco Survey (1993-2007) is an ongoing monthly randomdigit-dial telephone survey of approximately 6200 adults conducted using computer assisted telephone interviewing by the survey research group, Public Health Institute. Data were weighted to the 2000 California population using gender, four race groups and two age groups. Additional information on the methodology is available in a paper by Wayland et al. ${ }^{76}$ The California Tobacco Survey is a cross-sectional random-digit-dial telephone survey conducted approximately every 3 years since 1990 by the University of California, San Diego, Cancer Prevention and Control Center and Westat, Inc to measure changes in attitudes and behaviours in the California popula- tion. It has a sample size of approximately 30575 screener households. Oversampling of racial/ethnic groups and inlanguage survey methods are used to ensure adequate sample sizes within subpopulation groups. Data were weighted to the 2005 Current Population Survey, California population. Additional information on the methodology is available in a paper by Al-Delaimy et al. ${ }^{77}$

The California Student Tobacco Survey (2002-2006) is a school-based survey conducted among approximately 17000 students in over 300 middle (grades 6-8) and high schools (grades 9-12). The data were weighted to the 2005 population of California in-school youth, by gender, grade level and race/ ethnicity. Further information about the methods is available in a paper by McCarthy et al. ${ }^{78}$

\section{Limitations}

It is not possible to determine that the changes documented among adults, students and tobacco company marketing practices are the result of exposure to the media, policy and enforcement interventions. This is due to the cross-sectional nature of the population survey data and the lack of measures that determine the extent of exposure of adults and youths to specific tobacco marketing-related media, programme and enforcement interventions. However, the triangulation of data from multiple sources increases confidence in the individual survey results and the conclusions drawn about progress.

\section{RESULTS}

\section{Event sponsorship results}

Tobacco event sponsorship was monitored at large public events at risk of tobacco sponsorship such as rodeos, motorsports or other events with a history of tobacco sponsorship. Tobacco company, brand names, youth participation and free tobacco product distribution were key variables that were observed. Simple description statistics were used to analyse the data. As depicted in table 1, from 2001 to 2008, the percentage of observed events with tobacco industry sponsorship declined from $77.3 \%$ to $48.1 \%$. As displayed in table 2, in 2001, the percentage of events with smokeless tobacco and cigarette company sponsorship collectively were comparable with each having a presence at $60 \%$ of the events observed. In subsequent years, smokeless tobacco dominated event sponsorship. In 2008, USST or its brands sponsored $79 \%$ of events in comparison to Philip Morris/Altria at 21\%.

As displayed in table 3, rodeo-related events represented approximately one-half or more of the total number of tobacco industry-sponsored events each year. During 2007 and 2008, the percentage of tobacco industry-sponsored music or performing art events increased from previous years and is now on par with racing, a more traditional tobacco venue.

The non-sale distribution of tobacco products (eg, free tobacco samples and coupons for tobacco products) and youth involvement activities are sometimes found at tobacco industry-sponsored events. As depicted in table 4, during the six observation periods the proportion of events with youth participation generally declined; however, more than one-third (36.8\%) of

Table 1 Percentage of observed events with tobacco industry sponsorship, 2001-2003 and 2006-2008

\begin{tabular}{|c|c|c|c|c|c|}
\hline $\begin{array}{l}2001 \\
n=88\end{array}$ & $\begin{array}{l}2002 \\
n=80\end{array}$ & $\begin{array}{l}2003 \\
n=91\end{array}$ & $\begin{array}{l}2006 \\
n=68\end{array}$ & $\begin{array}{l}2007 \\
n=80\end{array}$ & $\begin{array}{l}2008 \\
n=79\end{array}$ \\
\hline 77.3 & 77.2 & 67.0 & 58.8 & 56.3 & 48.1 \\
\hline
\end{tabular}


Table 2 Percentage of tobacco industry sponsored events by tobacco company*, 2001-2003 and 2006-2008

\begin{tabular}{|c|c|c|c|c|c|c|}
\hline Tobacco company & $\begin{array}{l}2001 \\
n=68\end{array}$ & $\begin{array}{l}2002 \\
n=58\end{array}$ & $\begin{array}{l}2003 \\
n=61\end{array}$ & $\begin{array}{l}2006 \\
n=40\end{array}$ & $\begin{array}{l}2007 \\
n=45\end{array}$ & $\begin{array}{l}2008 \\
n=38\end{array}$ \\
\hline USST & 60.3 & 77.6 & 77.0 & 95.0 & 84.4 & 78.9 \\
\hline Philip Morris/Altria & 19.1 & 20.7 & 11.5 & 5.0 & 15.6 & 21.1 \\
\hline RJ Reynolds & 25.0 & 6.9 & 13.1 & 2.5 & 2.2 & 0 \\
\hline Lorillard & 16.2 & 5.2 & 1.6 & 0 & 0 & 0 \\
\hline Swedish Match & 0 & 0 & 1.1 & 0 & 0 & 0 \\
\hline
\end{tabular}

*A single event may have been sponsored by multiple tobacco companies or brands. If a tobacco company and one or more of its brands were event sponsors, the sponsorship was counted only once for the tobacco company (eg, a dual Skoal and Copenhagen sponsorship was only counted as one USST sponsored event). If an event was sponsored by brands of two different tobacco companies, the sponsorship was counted twice, once for each tobacco company, (eg, if an event were sponsored by both Winston and Skoal it was counted as one RJR sponsored event and as one USST sponsored event).

tobacco industry-sponsored events still included youth participation either as competitors in races, riding or mutton-busting events, or they carried flags or banners at event ceremonies, demonstrating the long-term strategic nature of tobacco sponsorship in 2008. Overall, there was no real decline in the proportion of tobacco industry-sponsored events that offered free tobacco product sampling with the proportion ranging from a low of $11.5 \%$ of events in 2003 rising to $24.4 \%$ in 2006 and then declining to $18.4 \%$ in 2008 .

\section{Tobacco retail advertising results}

Tobacco advertising in the retail environment has been monitored since 2000. From these surveys, key variables related to the saturation of retail tobacco advertising, its placement and compliance with state laws are presented. Table 5 presents the change in the average number of cigarette marketing materials per store for 2000, 2004 and 2008. It rose in 2004, but remained constant throughout the observation period.

Table 6 depicts the change in the percentage of stores with at least one cigarette advertisement promoting a price discount and the percentage of stores placing cigarette advertisements within six inches of candy and placed at or below three feet. The placement of advertisements near candy and placement of advertisements under three feet declined from 2002 to 2008; however, the percentage of stores with at least one advertisement promoting a price discount increased.

Between 2000 and 2004, there was a large increase in the proportion of stores that had a least one required warning sign posted, rising from $53.6 \%$ (95\% CI $49.0 \%$ to $57.3 \%$ ) in 2000 to $66.2 \%$ (95\% CI $62.2 \%$ to $70.2 \%$ ) in 2008 . However, as depicted by table 7 , in 2008 a greater proportion of stores posted the tobacco industry-produced We Card sign rather than the age-ofsale warning sign required by California law. In contrast, more than $99 \%$ of stores complied with the state law banning selfservice displays of tobacco products in 2008.

Table 3 Percentage of tobacco industry sponsored events by event type, 2001-2003 and 2006-2008

\begin{tabular}{|c|c|c|c|c|c|c|}
\hline Event type & $\begin{array}{l}2001 \\
n=68\end{array}$ & $\begin{array}{l}2002 \\
n=58\end{array}$ & $\begin{array}{l}2003 \\
n=61\end{array}$ & $\begin{array}{l}2006 \\
n=40\end{array}$ & $\begin{array}{l}2007 \\
n=45\end{array}$ & $\begin{array}{l}2008 \\
n=38\end{array}$ \\
\hline Rodeo* & 50.0 & 62.1 & 49.1 & 70.0 & 71.1 & 57.9 \\
\hline Motorsport $†$ & 32.4 & 20.7 & 36.1 & 27.5 & 11.1 & 21.1 \\
\hline Music or performing arts & 14.7 & 10.3 & 1.6 & 2.5 & 17.8 & 21.1 \\
\hline Other events & 2.9 & 6.9 & 13.1 & 0 & 0 & 0 \\
\hline
\end{tabular}

* Rodeo events include rodeo, bull riding and team roping.

†Motorsport events include auto and motorcycle racing.
Table 4 Percentage of tobacco industry sponsored events with nonsale distribution of tobacco products or youth participation activities, 2001-2003 and 2006-2008

\begin{tabular}{lllllll}
\hline & $\begin{array}{l}\mathbf{2 0 0 1} \\
\mathbf{n = 6 8}\end{array}$ & $\begin{array}{l}\mathbf{2 0 0 2} \\
\mathbf{n = 5 8}\end{array}$ & $\begin{array}{l}\mathbf{2 0 0 3} \\
\mathbf{n = 6 1}\end{array}$ & $\begin{array}{l}\mathbf{2 0 0 6} \\
\mathbf{n = 4 0}\end{array}$ & $\begin{array}{l}\mathbf{2 0 0 7} \\
\mathbf{n = 4 5}\end{array}$ & $\begin{array}{l}\mathbf{2 0 0 8} \\
\mathbf{n = 3 8}\end{array}$ \\
\hline $\begin{array}{l}\text { Non-sale distribution } \\
\text { of tobacco products* }\end{array}$ & 16.2 & 22.4 & 11.5 & 22.5 & 17.8 & 18.4 \\
$\begin{array}{l}\text { Youth participation } \\
\text { events† }\end{array}$ & 44.1 & 43.1 & 54.1 & 52.5 & 44.4 & 36.8 \\
\hline
\end{tabular}

*Defined as free tobacco product or coupon giveaways.

†Defined as events in which participants or competitors were under 18 years of age-for example, racing or riding contestants, mutton-busting participants, carried flags or banners.

\section{Adult and youth attitudes and exposure results}

Attitudes, beliefs and exposure to tobacco marketing are tracked through adult telephone surveys and in-school surveys. Key data are presented that relate to support for regulating tobacco marketing and exposure to tobacco sponsorship.

In 2007, California adults expressed strong support for regulating tobacco marketing: $76.4 \%$ (95\% CI $74.4 \%$ to $78.4 \%$ ) agreed that tobacco products should be regulated as a drug by a government agency such as the Food and Drug Administration (FDA); $75.0 \%$ (95\% CI $73.9 \%$ to $76.0 \%$ ) agreed that a ban on cigarette advertising should be extended to all print and electronic media; and $78.2 \%$ (95\% CI $77.2 \%$ to $79.3 \%$ ) agreed that advertising tobacco products at sports and athletic events should be banned. ${ }^{79}$ Seeing tobacco advertisements at sporting and community events and reported attendance at a tobacco company-sponsored event in the past year declined among youths and adults compared to earlier years. The proportion of high school students reporting they had seen tobacco advertisements at sport or community events declined significantly from $58.1 \%$ to $52 \%$ ( $p$ value $<0.001$ ) between 2002 and $2006 .{ }^{80}$ The proportion of adults who reported attending a tobacco company-sponsored event in the past year also declined significantly from $19 \%$ in 2002 to $14.0 \%$ in 2005 ( $p$ value <0.001). ${ }^{81}$

\section{DISCUSSION}

Since the mid-1990s, the CTCP has raised awareness about the influence that tobacco marketing has on tobacco use. Its media campaign, statewide advocacy campaigns and the partnership with the California Attorney General's Office sought to curb tobacco marketing through a variety of voluntary, legislated and enforcement approaches.

Since 2000, there was little change in the overall average number of cigarette marketing materials per store but there was a substantial increase in the percentage of stores with advertising promoting price discounts for cigarettes. Progress was made in decreasing the percentage of stores placing tobacco advertisements near candy displays (reduced to $1 \%$ of stores) and at the eye-level of young children (reduced from $78.6 \%$ to $31.0 \%$ ). Compliance with posting required age-of-sale warning signs increased significantly, but remained substantially lower than posting of the tobacco industry's We Card sign $(66.2 \%$ vs $94.0 \%)$.

Table 5 2000-2008: average number of cigarette marketing materials per store

\begin{tabular}{llll}
\hline Saturation or placement & $\begin{array}{l}\mathbf{2 0 0 0} \\
(\mathbf{n}=\mathbf{5 6 2})\end{array}$ & $\begin{array}{l}\mathbf{2 0 0 4} \\
\mathbf{( n = 5 6 5 )}\end{array}$ & $\begin{array}{l}\mathbf{2 0 0 8} \\
\mathbf{( n = 5 4 5 )}\end{array}$ \\
\hline $\begin{array}{l}\text { Average number of cigarette } \\
\text { marketing materials }\end{array}$ & $19.1(\mathrm{SD}=18.6)^{1}$ & $26.1(\mathrm{SD}=25.2)$ & $17.6(\mathrm{SD}=11.2)$ \\
\hline
\end{tabular}


Table 6 2002-2008: percentage of stores with at least one cigarette advertisement promoting a price discount and placement of advertising in a location that may appeal to youths

\begin{tabular}{|c|c|c|c|c|c|c|}
\hline Saturation or placement & $\begin{array}{l}2002^{*} \\
(n=569)\end{array}$ & (95\% CI) & $\begin{array}{l}2004 \\
(n=565)\end{array}$ & $(95 \% \mathrm{CI})$ & $\begin{array}{l}2008 \\
(n=545)\end{array}$ & $(95 \% \mathrm{CI})$ \\
\hline $\begin{array}{l}\text { At least one cigarette advertisement } \\
\text { with a price discount }\end{array}$ & 68.4 & (64.5 to 72.2$)$ & 74.3 & (70.7 to 78.0$)$ & 78.5 & $(75.0$ to 82.0$)$ \\
\hline Advertisements near candy & 12.5 & (9.8 to 15.2$)$ & 12.9 & (10.1 to 15.7$)$ & 1.1 & $(0.2$ to 1.9$)$ \\
\hline Advertisements at or below 3 feet & 78.6 & (75.2 to 82.0$)$ & 77.9 & (74.5 to 81.3$)$ & 31.0 & (27.1 to 34.9$)$ \\
\hline
\end{tabular}

The continued saturation of stores with cigarette advertising and increase in price promotion advertisements mirrors the emphasis seen in tobacco company expenditures for point-ofsale retail advertising and price-related marketing. The high rate of retailers posting We Card signs is probably a function of contract requirements between tobacco companies and stores. These contracts require specific marketing provisions in return for price promotions aimed to stimulate sales. ${ }^{29}$ This situation may improve as local tobacco retail licensing ordinances earmarking a portion of the licence fees for enforcement are enacted, but a straightforward solution would be for tobacco companies to incorporate mandated age-of-sale signage requirements into their price promotion contracts.

Overall there was a decline in the number and percentage of tobacco-sponsored events between 2001 and 2008. This is consistent with the significant decline noted among high school students and adults who reported seeing tobacco advertisements at events or attending a tobacco company-sponsored event. There was a marked shift towards smokeless tobacco-related sponsorships and rodeo-related event sponsorship, which may reflect an industry-wide move to add smokeless tobacco products to their promoted brands.

The pervasiveness of free tobacco product sampling at events remained relatively unchanged over the six observation periods. A modest decline in youth participation-oriented activities at tobacco-sponsored events was observed, but more than onethird (36.8\%) of them continued to include these activities. Repeated enforcement action was taken against RJ Reynolds and USST to address compliance with the MSA/STMSA and the state restriction on no-cost tobacco distribution. This suggests that partial bans on tobacco marketing provide greater opportunity to test limits or may be difficult to understand.

Tobacco industry monitoring data were used to develop media and policy interventions such as the Ken Lane and Grim Reapers advertisements and statewide advocacy campaigns. The data also helped to forge a partnership with the California Attorneys General's Office. Consequently, substantial enforcement operations and voluntary agreements were achieved. These resulted in new resources for tobacco control work including regular correspondence from the tobacco companies about the date and location of free tobacco sampling activities and earmarking

Table 72008 Percentage of tobacco stores posting tobacco sale signage

\begin{tabular}{|c|c|c|c|}
\hline & $\begin{array}{l}\text { Year legal } \\
\text { requirement enacted }\end{array}$ & $\begin{array}{l}\text { Percentage } \\
(\mathrm{n}=)\end{array}$ & $(95 \% \mathrm{Cl})$ \\
\hline State tobacco retail licence & 2003 & $45.3(536)$ & $(41.0$ to 50.0$)$ \\
\hline Age-of-sale warning sign & 1994 & $66.2(545)$ & (62.2 to 70.2$)$ \\
\hline $\begin{array}{l}\text { Tobacco industry } \\
\text { We Card sign }\end{array}$ & Not required by law & $93.8(545)$ & (91.8 to 95.8 ) \\
\hline
\end{tabular}

a portion of payments resulting from enforcement action towards tobacco control efforts.

Local tobacco control ordinances restricting tobacco marketing before the 2001 US-Supreme Court decision Lorillard $\mathrm{v}$ Reilly along with the current level of public support for tobacco marketing restrictions suggests that California communities are well-positioned to seize opportunities afforded by the Family Smoking Prevention and Tobacco Control Act. This federal legislation implements a number of new marketing restrictions and gives the US Food and Drug Administration (FDA) comprehensive authority to regulate the manufacturing, marketing and sale of tobacco product. It also eliminates the preexisting federal pre-emption of the state and local restrictions on the time, place or manner of cigarette advertising for public health purposes. $^{82}$

Despite these new opportunities, numerous challenges remain. Monitoring tobacco industry marketing is difficult owing to its sheer volume, diversity and pervasiveness. ${ }^{14}$ The task has become increasingly formidable given the industry's agile response to US restrictions on the use of television, radio, billboard, sponsorship and magazine advertisement placement and use of technology. Data collection at tobacco industrysponsored bar nights, fraternity parties and adult-only facilities relies on labour-intensive methods vastly different from surveillance systems traditionally used to monitor communicable diseases or to track cancer. Monitoring the nature and extent of direct mail marketing is difficult, as tobacco industry practices incorporate the use of sophisticated technology to create one-on-one relationships with consumers through the use of contests, the internet, coupons, direct mail, email and mobile marketing. 83 The First Amendment and tobacco industry opposition will continue to create hurdles to the enactment of comprehensive bans on tobacco marketing. Yet, there is considerable evidence that restrictions to curb the impact of tobacco marketing are most effective at reducing tobacco consumption when they are comprehensive. ${ }^{85-88}$

Given these challenges, a network among state and federal agencies including attorneys general is needed to coordinate efforts and resources to uniformly monitor tobacco industry marketing, improve state-specific marketing reporting by tobacco companies, leverage legal technical assistance resources, coordinate enforcement actions to achieve a greater deterrent effect and disseminate educational and media materials to raise awareness and facilitate policy adoption. ${ }^{1}$ The FDA legislation provides a tool to start this work, but success depends on how well local, state and national partners can execute meaningful policies and their agility at identifying and effectively responding to the tobacco industry's response to use of nonrestricted media and new marketing techniques. The convening and investment of public health, surveillance, legal and marketing experts to facilitate this complex, but important work should be a high priority among state and federal agencies. 


\section{What this paper adds}

This paper illustrates the integration of tobacco industry monitoring with the implementation of mass media campaigns, policy enactment and enforcement efforts. It provides a framework for comprehensive tobacco control programmes in the United States as they move to act upon the opportunities afforded by the 2009 Family Smoking Prevention and Control Act. This federal legislation implements a number of new tobacco marketing restrictions and provides new legal authority for state, local and tribal governments to restrict the time, place and manner of cigarette advertising for public health purposes. Additionally, this paper highlights areas of continued concern regarding marketing practices at events and in the retail environment.

Acknowledgements We thank Nina Schleicher for assistance with the analysis of the retail tobacco data. We thank David Cowling, Mary Modayil and Tonia Hagaman for assistance with comments on earlier versions and assistance with the sponsorship data.

\section{Competing interests None.}

Contributors All authors contributed to the conception and design of the study and the acquisition of the data. ECF analyzed and interpreted the retail tobacco advertising data. TCB and AR analyzed and interpreted the tobacco sponsorship data. AR drafted the article and all authors revised it critically for important intellectual content. All authors had final approval of the version published.

Provenance and peer review Not commissioned; externally peer reviewed.

\section{REFERENCES}

1. Cruz TB. Monitoring the tobacco use epidemic IV. Tobacco industry data sources and recommendations for research and evaluation. Prev Med 2009;48(Suppl 1): s24-34

2. Lovato C, Linn G, Stead LF, et al. Impact of tobacco advertising and promotion on increasing adolescent smoking behaviors. Cochrane Database Syst Rev 2003;(4): CD003439. http://mrw.interscience.wiley.com/cochrane/clsysrev/articles/CD003439/ pdf fs.html (accessed 4 Apr 2009).

3. US Department of Health and Human Services. Reducing tobacco use: a report of the Surgeon General. Atlanta, GA: US Department of Health and Human Services, Centers for Disease Control and Prevention, National Center for Chronic Disease Prevention and Health Promotion, Office on Smoking and Health, 2000.

4. National Cancer Institute. The role of media in promoting and reducing tobacco use. Tobacco Control Monograph No. 19. Bethesda, MD: US Department of Health and Human Services, national Institutes of Health, national Cancer Institute. NIH Pub. No. 07-6242, 2008

5. Paynter J, Edwards R. The impact of tobacco promotion at the point of sale: a systematic review. Nicotine Tob Res 2009;1:25-35.

6. Loomis BR, Farrelly MC, Mann NH. The association of retail promotions for cigarettes with the master settlement agreement, tobacco control programmes and cigarette excise taxes. Tob Control 2006;15:458-63.

7. Slater S, Chaloupka FJ, Wakefield M. State variability in retail promotions and advertising for Marlboro cigarettes. Tob Control 2001;10:337-9.

8. Chaloupka F, Cummings K, Morley $\mathrm{C}$, et al. Tax, price and cigarette smoking: evidence from the tobacco documents and implications for tobacco company marketing strategies. Tob Control 2002;11(Supp 1):i62-72.

9. Pierce JP, Glimer TP, Lee $L$, et al. Tobacco industry price-subsidizing promotions may overcome the downward pressure of higher prices on initiation of regular smoking. Health Econ 2005;14:1061-71.

10. Givel MS, Glantz SA. Tobacco lobby political influence on US state legislatures in the 1990s. Tob Control 2001;10:124-34.

11. Rosenberg NJ, Siegel M. Use of corporate sponsorship as a tobacco marketing tool: a review of tobacco industry sponsorship in the USA, 1995-99. Tob Control 2001;10:239-46

12. Hastings G, Liberman J. Tobacco corporate social responsibility and fairy godmothers: the Framework Convention on Tobacco Control slays a modern myth Tob Control 2009;18:73-4.

13. Tesler LE, Malone RE. Corporate philanthropy, lobbying and public health policy. Am J Public Health 2008;98:2123-33.

14. Traynor MP, Begay ME, Glantz SA. New tobacco industry strategy to prevent local tobacco control. JAMA 1993;270:479-86.
15. Yerger VB, Malone RE. African American leadership groups: smoking with the enemy. Tob Control 2002;11:336-45

16. Chapman S. Advocacy in action: extreme corporate makeover interruptus: denormalising tobacco industry corporate schmoosing. Tob Control 2004 13:445-7.

17. Dewhirst T, Hunter A. Tobacco sponsorship of Formula One and CART auto racing: tobacco brand exposure and enhanced symbolic imagery through co-sponsors' third party advertising. Tob Control 2002;11:146-50.

18. Dewhirst T, Sparks R. Intertextuality, tobacco sponsorship of sports, and adolescent male smoking culture: a selective review of tobacco industry documents. Journal of Sport and Social Issues 2003:27:372-98.

19. Atiken PP, Leathar DS, Squair SI. Children's awareness of cigarette brand sponsorship of sports and games in the UK. Health Educ Res 1986:1:203-11.

20. Ledwith F. Does tobacco sports sponsorship on television act as advertising to children? Health Educ J 1984;43:85-8.

21. Sparks R. Youth awareness of tobacco sponsorship as a dimension of brand equity. International Journal of Sports Marketing and Sponsorship 1999;1:236-60.

22. Hoek J, Gendall P, Stockdale M. Some effects of tobacco sponsorship advertisements on young males. International Journal of Advertising 1993; 12:25-36

23. Cornwell TB. State of the art and science in sponsorship-linked marketing Journal of Advertising 2008;37:41-55.

24. Biener $\mathbf{L}$, Albers $A B$. Young adults: vulnerable new targets of tobacco marketing. Am J Public Health 2004:94:326-30.

25. Chaloupka FJ. Written direct examination United States of American v. Philip Morris. 99-CV-02496 (GK). United States District Court for the District of Columbia 2004. http://www.usdoj.gov/civil/cases/tobacco2/Chaloupka\%20Direct\%20-\%20final. pdf (accessed Sep 2009).

26. Rigotti NA, Moran SE, Wechsler H. US college students' exposure to tobacco promotions: prevalence and association with tobacco use. Am J Public Health 2005:95:138-44.

27. Federal Trade Commission. Federal trade commission cigarette report for the year 2006. Washington DC: US Federal Trade Commission, 2009. http://www2.ftc.gov/ os/2009/08/090812cigarettereport.pdf (accessed 11 Sep 2009).

28. Federal Trade Commission. Federal trade commission smokeless tobacco report for the years 2006. Washington DC: US Federal Trade Commission, 2009. http:// www2.ftc.gov/os/2009/08/090812smokelesstobaccoreport.pdf laccessed 11 Sep 2009)

29. Feighery EC, Ribisl KM, Clark PI, et al. How tobacco companies ensure placement of their advertising and products in stores: interviews with retailers and tobacco company incentive programmes. Tob Control 2003;12:184-8.

30. Loomis B, Farrelly M, Nonnemaker J, et al. Point of purchase cigarette promotions before and after the master settlement agreement: exploring retail scanner data. Tob Control 2006:15:140-2.

31. Wakefield M, Terry-McElrath YM, Chaloupka FJ, et al. Tobacco industry marketing at point of purchase after the 1998 MSA billboard advertising ban. Am J Public Health 2002:92:937-40.

32. Centers for Disease Control and Prevention, Media Campaign Resource Center 2009. http://apps.nccd.cdc.gov/MCRC/Apps/QuickSearch.aspx (accessed Sep 2009).

33. California Department of Public Health. Grim reapers, 2009. http://www. tobaccofreeca.com/ads tv.html (accessed Apr 2009).

34. Anon. Operation Storefront Phase / Training: youth against tobacco advertising and promotion. Sacramento, CA: California Department of Health Services, Tobacco Control Section and Stanford University, Stanford Center for Research in Disease Prevention, 1994

35. Anon. Operation Storefront phase // training: assessing community readiness. Sacramento, CA: California Department of Health Services, Tobacco Control Section and Stanford University, Stanford Center for Research in Disease Prevention, 1994

36. Anon. Operation Storefront Phase III Training: youth against tobacco advertising and promotion. Sacramento, CA: California Department of Health Services, Tobacco Control Section and Stanford University, Stanford Center for Research in Disease Prevention, 1996.

37. Tencati E, Howard-Pitney B, Roeseler AG, et al. Operation Storefront: Five case studies of phase III projects. Sacramento, CA: California Department of Health Services, Tobacco Control Section, 1996.

38. California Department of Health Services, Tobacco Control Section and Stanford University, Stanford Center for Research in Disease Prevention. Operation Storefront Phase IV: Taking the next step. California Department of Health Services, Tobacco Control Section, 1996.

39. California Department of Health Services, California Tobacco Control Section. Operation Storefront 1997: maximizing media coverage of your results. California Department of Health Services, California Tobacco Control Section, 1997.

40. Belanger L, Kent S, Flynn P. Racing toolkit: helping motorsports get free of tobacco sponsorship. Sacramento, CA: California Department of Health Services, 2004.

41. Belanger L, Flynn P. Rodeo toolkit: for tobacco prevention advocates helping rodeos become tobacco free. Sacramento, CA: California Department of Health Services, 2001.

42. Belanger L, Flynn P. Tack and tools for rodeo organizers. Sacramento, CA: California Department of Health Services, 2001

43. California Department of Public Health. California Tobacco Control Program. STORE Campaign website, 2002. http://www.tcsstore.org/ (accessed Sep 2009) 
44. Rogers T, Feighery EC, Tenacti EM, et al. Community mobilization to reduce point of purchase advertising of tobacco products. Health Educ 0 1995;22:427-42.

45. American Nonsmokers' Rights Foundation. Ordinances Restricting Tobacco Advertising, 2001 Dec 10. http://www.nsmoke.org.

46. University of Southern California Tobacco Industry Monitoring Evaluation Project SMART Money: The local policies index: policies to keep California organizations, businesses and events tobacco free. Los Angeles, California, USA University of Southern California, TIME Project, 2004.

47. Buck Tobacco Sponsorship. Policies restricting tobacco sponsorship at rodeos in California, 2009. http://www.bucktobacco.org/policy/index.html (accessed Nov 2009)

48. California Youth Advocacy Network. College advertising and marketing policies. Sep 2009. http://www.cyanonline.org (accessed 12 Sep 2009).

49. State of California. California Health and Safety Code Section118950, 2008. http:// www.leginfo.ca.gov/cgi-bin/waisgate?WAISdoclD $=73730216050+0+0$ + 0\&WAISaction=retrieve (accessed Sep 2009)

50. Americans for Nonsmokers' Rights Foundation. California municipalities with sampling laws. 2009 Jul 6. http://bucktobacco.org/policy/SamplingLaws-CA-200910-02.pdf (accessed 12 Sep 2009).

51. Chico Municipal Code Chapter 9.18. Nonsale distribution of smokeless tobacco or cigarettes, 2008. http://www.chico.ca.us/document_library/municode/Title_9.pdf (accessed Apr 2009).

52. American Lung Association of California Center for Tobacco Policy and Organizing. Prohibiting sample of tobacco products through a local ordinance, Jul 2009. http://www.center4tobaccopolicy.org/_files/_files/Prohibiting\%20Sampling \%20of\%20Tobacco\%20Products\%20through\%20a\%20Local\%200rdinance.pdf (accessed 12 Sep 2009).

53. Brantley S. Final evaluation report-American Lung Association of California: City of Chico Tobacco Distribution Policy. Chico, CA: American Lung Association of California, 2009.

54. Americans for Nonsmokers Rights' Foundation. California municipalities with laws restricting youth access to tobacco products, 2009 Jul 1. http://www.phlpnet. org/tobacco-control/products/anrf-list-communities-licensing-and-self-servicedisplay-ordinances (accessed 12 Sep 2009).

55. California Department of Public Health. California tobacco control program. California tobacco control update 2009: 20 years of tobacco control in California: Sacramento, CA: California Department of Public Health, 2009. http://www.cdph.ca. gov/programs/tobacco/Documents/CTCPUpdate2009.pdf (accessed 15 Sep 2009).

56. State of California. Senate Bill 1766, Chapter 686, 2001. http://www.leginfo.ca. gov/pub/01-02/bill/sen/sb 1751-1800/sb 1766 bill 20020918 chaptered.pdf (accessed 16 Sept 2009).

57. State of California. Senate Bill 1173, Chapter 812, 2004. http://www.leginfo.ca. gov/pub/03-04/bill/sen/sb_1151-1200/sb_1173_bill_20040927_chaptered.pdf (accessed 16 Sep 2009).

58. California Attorney General's Office. Attorney General's Office enters into settlement agreement with RJ Reynolds concerning activities at brand name sponsorship events, announcement, May 2000. http://ag.ca.gov/tobacco/pdf/1bns. pdf (accessed 12 Sep 2009).

59. California Attorney General's Office. Settlement agreement between the Attorney General's Office and RJ Reynolds Tobacco Company, May 2000. http://ag ca.gov/tobacco/pdf/bns ag3.pdf (accessed 12 Sep 2009)

60. California Attorney General's Office. Attorney general reaches settlement agreement with United States Tobacco Company over alleged advertisement violations. press release, 2000 Dec 6. http://ag.ca.gov/newsalerts/release.php? id=760 (accessed 12 Sep 2009).

61. California Attorney General's Office. Settlement agreement between California Attorney General's Office and US Tobacco Company smokeless tobacco advertisements, 2001 Nov. http://ag.ca.gov/tobacco/pdf/chewsett.pdf (accessed 12 Sep 2009)

62. California Attorney General's Office. Attorney General Lockyer announces settlement of free tobacco samples lawsuit, press release, 2001 Jul 13. http://ag.ca. gov/newsalerts/release.php?id=1322 (accessed 12 Sep 2009).

63. People of the State of California ex rel. Bill Lockyer, Attorney General of the State of California v. Swedish Match North America Inc. free smokeless tobacco sampling on public property in California stipulation for order and order for entry of final judgment and permanent injunction signed by Judge Robert B. Yonts Jr. on 2001 Jun 21. http://ag.ca.gov/tobacco/pdf/Swedish Match.pdf (accessed 12 Sep 2009)

64. California Attorney General's Office. US Smokeless Tobacco Company agreement relating to brand name sponsorship: memorandum of understanding concerning adult-only facilities. 2002 Jul 31. http://ag.ca.gov/tobacco/pdf/ UST MOU.pdf (accessed 12 Sep 2009).

65. California Attorney General's Office. Attorney General Lockyer settles lawsuit over illegal distribution of smokeless tobacco products, press release, 2002 Oct 17. http://ag.ca.gov/newsalerts/release.php?id=1005 (accessed 12 Sep 2009).

66. Stipulation for order and proposed order for entry of a final judgment and permanent injunction. Superior Court, 2002 Oct 17. http://ag.ca.gov/newsalerts/cms02/02-120. pdf (accessed 12 Sep 2009).
67. People of the State of California v. RJ Reynolds Tobacco Company. $107 \mathrm{Cal}$ App 4th 516, 132 Cal. Rptr 2d. 151, 2003. http://ag.ca.gov/tobacco/pdf/decision.pdf (accessed 12 Sep 2009).

68. People of the State of California ex rel. Attorney General Bill Lockyer v. RJ Reynolds Tobacco Company stipulation for order and order for entry of final judgment signed by Judge Ronald S. Prager, 2004 Mar 23. http://ag.ca.gov/tobacco/pdt/ StipOrder.pdf (accessed 12 Sep 2009).

69. California Attorney General's Office. Attorney General Lockyer announces $\$ 5$ million settlement with RJ Reynolds to resolve lawsuit over firm's distribution of free cigarettes, press release, 2006 May 8. http://ag.ca.gov/newsalerts/release.php? id =1301. (accessed 12 Sep 2009).

70. People for the State of California, ex rel Bill Lockyer, v. RJ Reynolds Tobacco Company signed by Dennis Eckhart, Esq, State of California, Department of Justice and $\mathrm{H}$. Joseph Escher II, Attorney for RJ Reynolds Tobacco Company. 2006 Mar 22. http://ag.ca.gov/newsalerts/cms06/06-048 0a.pdf laccessed 12 Sep 2009).

71. People for the State of California, ex rel Bill Lockyer, Attorney General v. US Smokeless Tobacco Company stipulation for entry of judgment and final judgment singed by Judge Ronald S. Prager. 2007 Aug 20. http://ag.ca.gov/tobacco/pdf/usstc pdf (accessed 12 Sep 2009).

72. California Attorney General's Office. Attorney General Lockyer announces agreement with 7-Eleven to curb tobacco sales to minors, press release, 2005 Aug 11. http://ag.ca.gov/newsalerts/release.php?id=1188 (accessed 12 Sep 2009)

73. Unger JB, Cruz TB, Feighery EC. Tobacco advertising in retail outlets in California, 2000-2004. Sacramento, CA: California Department of Health Services, Tobacco Control Section, 2007. http://www.tcsrover.org/catalog/files/ CTCPAdvertisingRetailOutletsCA.pdf (accessed 23 Sep 2009).

74. California Department of Justice. Biennial report, major activities 2007-2008. Sacramento, CA: California Department of Justice, 2008. http://ag.ca.gov/ publications/biennial report 07-08.pdf\#xml=http://search.doj.ca.gov:8004/ AGSearch/isysquery/0782d7̄a1-77b4-4b3e-bac0-9906296bcbfc/5/hilite/ laccessed 24 Oct 2009).

75. Feighery EC, Schleicher NC, Cruz BT, et al. An examination of trends in amount and type of cigarette advertising and sales promotions in California stores, 2002-2005. Tob Control 2008:17:93-8

76. Wayland S, Induni M, Davis B. California adult tobacco survey SAS dataset documentation and technical report: 1993-2007. Survey Research Group, Cancer Surveillance and Research Branch, California Department of Public Health, 2008. Report: http://www.surveyresearchgroup.org/sub.php?page=projects adult tobacco (accessed 2 Oct 2008).

77. Al-Delaimy WK, Messer K, Pierce JP, et al. Technical report on analytic methods and approaches use in the 2005 California Tobacco Survey Analysis. Vol 1: data collection methodology. La Jolla, CA: University of California, San Diego, 2007. http://ibraries. ucsd.edu/ssds/pub/CTS/cpc00008/2005\%20Fina|\%20TECH\%20Report-Vol.\%201.pdf (accessed 2 Oct 2008)

78. McCarthy WJ, Dietsch BJ, Dent C, et al. Evaluation of the In-School Tobacco Use Prevention Education Program, 2005-2006: technical findings and documentation. Sacramento, CA, USA: California Department of Public Health, California Tobacco Control Program, 2007.

79. California Adult Tobacco Survey (CATS), California Department of Public Health. Sacramento, CA, 2007

80. C-STATS. Percent of youth who see advertisements for cigarettes or chewing tobacco sometimes or a lot when they go to sports events, fairs, or community events. California Student Tobacco Survey, 2002-2006. 2006. http://www.cstats. info/index.cfm?fuseaction=reports.html GenericSW\&delD $=80 \xi \mathrm{ttID}=11 \mathrm{q}$ deTableName=tbIMEY_1_SW \&location $=1 \& S W T y p e=$ GenericSW\&yalD $=1 \& C F I D=67572 \& C F T O K E N=$ d410ea646a406260-41B2BE73-1143-D8D6-116A94E2F5172DF6 laccessed Apr 2009)

81. Al-Delaimy WF, White MM, Trinidad DR, et al. The California tobacco control program: can we maintain the progress? Results from the California Tobacco Survey, 1990-2005. vol 2. La Jolla, CA: University of California San Diego, 2008.

82. H.R. 1256 Family Smoking Prevention and Control Act, 2009. http://thomas.loc.gov/ cgi-bin/query/D?c111:6:/temp/ c111ar39Kr (accessed Sep 2009).

83. Katz SK, Lavack AM. Tobacco related bar promotions: insights from tobacco industry documents. Tob Control 2002:11(Suppl 1):i92-101.

84. Lewis MJ, Delnevo CD, Slade J. Tobacco industry direct mail marketing and participation by New Jersey Adults. Am J Public Health 2004:94:257-9.

85. Saffer H, Chaloupka F. The effect of tobacco advertising bans on tobacco consumption. J Health Econ 2000;19:1117-37. Review.

86. Jha P, Chaloupka FJ, Corrao M, et al. Reducing the burden of smoking world-wide: effectiveness of interventions and their coverage. Drug Alcohol Rev 2006;25:597-609.

87. Quentin W, Neubauer S, Leidl R, et al. Advertising bans as a means of tobacco policy: a systemic literature review of time-series analyses. Int $J$ Public Health 2007:52:295-307.

88. Blecher E. The impact of tobacco advertising bans on consumption in developing countries. J Health Econ 2008;27:930-42. 


\section{APPENDIX 1}

\section{Highlights of California Attorney General Enforcement Actions}

\begin{tabular}{ll}
\hline $\begin{array}{l}\text { Tobacco company } \\
\text { or association }\end{array}$ & Enforcement action \\
\hline RJ Reynolds 2000 & $\begin{array}{l}\text { Violated MSA outdoor signage advertising provisions at sponsored events } \\
\text { and restrictions on free tobacco product distribution at the Winston Cup } \\
\text { National Association Stock Car Racing and National Hot Road Association } \\
\text { Drag Racing series }\end{array}$ \\
& $\begin{array}{l}\text { Violated California Health and Safety Code Section 118950 (prohibits } \\
\text { non-sale distribution of coupons for smokeless tobacco on public grounds) } \\
\text { with its placement of an Ultimate Playboy Weekend sweepstake contest } \\
\text { advertisement in the San Diego State University student newspaper } \\
\text { The Daily Aztec, which included a \$1.00-off coupon for Rooster } \\
\text { smokeless tobacco }\end{array}$
\end{tabular}

Swedish Match 2001 Violated California Health and Safety Code Section 118950 (prohibits non-sale distribution of smokeless tobacco on public grounds) at the Watsonville Speedway and the California Mid-State Fair in Paso Robles

RJ Reynolds $2001 \quad$ Violated MSA provisions related to restrictions of free tobacco product sampling with its nationwide programme that involved distributing massive quantities of free cigarettes through the mail to individuals' homes

USST 2002

USST 2002

RJ Reynolds 2003

RJ Reynolds 2004

RJ Reynolds 2005

RJ Reynolds 2006

USST 2007

USST 2009

USST 2009

RJ Reynolds 2009
Violated provisions of the MSA related to placement of advertisements in national magazines with a large youth readership

Violated California Health and Safety Code Section 118950 (prohibits nonsale distribution of cigarettes on public grounds) that occurred at six public events including the Pomona Raceway

Violated STMSA provisions related to adult-only facilities where free tobacco product sampling occurred and brand name advertising at these facilities

Violated Health and Safety Code Section 118950 (prohibits non-sale distribution of smokeless tobacco on public grounds) at Wild West Stampede in Auburn and Livermore Rodeo in Livermore

Violated MSA outdoor signage restrictions at the National Association for Stock Car Auto Racing Winston Cup Series at Sears Point Raceway and

Violated California Health and Safety Code Section 118950 (prohibits nonsale distribution of cigarettes on public grounds) by distributing free tobacco products outside of bars on the sidewalks of San Francisco

MSA violations related to a Skoal promotion at Hot Rod Association Drag Racing events where minors were allowed to compete

Violated STMSA provisions that restrict brand name sponsorship which occurred at Professional Bull Riders events

Violated California Health and Safety Code Section 118950 (prohibits nonsale distribution of coupons for smokeless tobacco on public grounds) that occurred at Pomona Raceway

Violated MSA provision related to the use of cartoons to advertise or promote cigarettes other auto race tracks
Outcome

Settlement agreement

- \$30000 payment for investigative costs

Established restrictions and standards for placement of advertising at events

- Established requirements to enclose booths where free tobacco product sampling was occurring to prevent youth exposure

- Settlement Agreement

- \$150000 payment to Rogers \& Associates to create and place an alternative advertisement and to pay for investigative fees and other damages

Stipulated court judgment

- \$375000 payment to the Public Health Institute to monitor tobacco advertising and promotions and raise awareness about tobacco use

- \$10200 payment for investigative costs

- Court approved settlement

- \$175000 payment to California and Arizona for investigative costs and attorney fees

- Established: requirements for written consent to receive samples for evaluation purposes; placed limits on the number of packs sent and the size of mail containers; and reporting requirements describing the number of packs distributed in the state

- Multi-state memorandum of understanding

- Requirements for enclosing booths where free tobacco product sampling was occurring to prevent youth exposure

- Established requirements on the use of brand name advertisements at facilities where free tobacco product sampling was occurring

- Stipulated court judgment

- \$150000 payment to the Public Health Institute for tobacco use prevention and cessation education related to tobacco products and tobacco brand name sponsorships

- \$21000 for investigation costs

- Court of Appeal decision

- Established restrictions to prohibit the placement of event signage more than 90 days before and 10 days after an event

- Superior Court decision

- \$60000 payment to the Public Health Foundation Enterprises for youth and young adult tobacco control advocacy efforts

- \$35000 for investigative costs

- Required RJ Reynolds to notify the California Attorney General's Office of the site and date of planned bar promotions in the month prior to the sampling activity (through December 2005)

- Stipulated court judgment (following successful appeal of permanent injunction and reversal of $\$ 20$ million penalty)

- \$11.4 million in penalties

- \$5.8 million in attorneys fees and costs

- Placed restrictions on the total gross number of impressions viewable by youth in youth-measured publications

- Superior Court decision

- \$5 million payment

-\$3.1 million civil penalties

-\$900000 attorney fees and costs

$-\$ 1$ million to Public Health Institute for training and education related to tobacco product promotion

- Superior Court decision

- Required the Hot Rod Association to adopt a rule that prohibited youths under the age of 18 from participating in its drag racing events

- \$1.5 million payment in attorney fees and other costs

- Stipulated court judgment

- Limited brand name sponsorship to events in a single national series of events

- Permitted no more than three riders on a sponsored team

- \$150000 payment to the Public Health Institute for tobacco use prevention and cessation education related to products and tobacco brand name sponsorships

- Court judgment

- Declaration that some images in Camel the Farm promotion were prohibited cartoons

- State entitled to attorneys fees (amount to be determined; case still pending) 